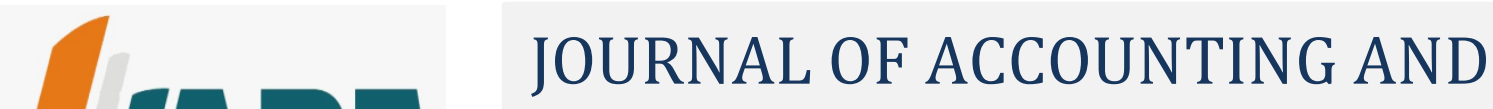 BUSINESS EDUCATION \\ P-ISSN 2528-7281 E-ISSN 2528-729X \\ E-mail: jabe.journal@um.ac.id
}

\section{The Implementation of INA-CBGs (Indonesia Case-Based Groups) System and Strategic Response in Institutional Theory Perspective (Case Research in RSUD Dr. Saiful Anwar Malang)}

\author{
Citrus Clarias \\ Eko G. Sukoharsono \\ Aji D. Mulawarman \\ Universitas Brawijaya \\ myclarias@gmail.com
}

\begin{abstract}
This research aimed to understand the implementation of INA-CBGs system and organization response in the institutional perspective at RSUD Dr. Saiful Anwar (RSSA). To achieve these objectives, a descriptive qualitative method was used with case study as a strategy. The implementation of INACBGs system was analyzed using the institutional forces that exist in the institutional theory of Dimaggio \& Powell (1983), and analysis of an organization's response was based on strategic responses of institutional forces by Oliver (1991). The results showed that coercive pressures in the implementation of the INA-CBGs system derived from government regulations. Source normative pressure came from the education and professional standards. Source mimetic pressures came from competition with other hospitals and the uncertainty of the health industry environment. The strategic response in facing coercive pressure was giving a passive approval and perform some strategic innovation. While the normative pressure was responded by training and a more selective recruitment process. Last response related to mimetic pressure was by imitating the existing practice from other hospitals.
\end{abstract}

Keywords: Institutional forces, INA-CBGs Systems, Strategic response

\section{INTRODUCTION}

Accounting can detect the probability of inefficient practice and improve performance in the public organization sector (Hopwood, 1992). The role of accounting in the health sector is realized through the payment system that is called as Diagnosis Related Group (DRG). In the constitution, No. 40 the year 2005 about the National Social Security System, Indonesia has been implementing the DRG system since 2014 by the name INA-CBGs system (Indonesian CaseBased Groups). This constitution brings out the new health insurance called as Jaminan Kesehatan Nasional (JKN) / National Health Insurance program. The national health insurance is 
given to all of society to get health services without worrying the cost. However, the weak controls toward this program cause the deficit of budget to ensure the health services. In a developing country such as Indonesia, the population growth is increasing faster which then increases the health service demand. This condition causes the fiscal deficit in the health sector. Besides the economic problem and social welfare, the other problem is an unlimited demand for health services without sufficient resources and budget (Forgione et al., 2009).

INA-CBGs system is implemented to make the government spending in health sector more efficient, INA-CBGs system is implemented in the hospital which is appointed as an advanced referral. The effect of this system raises a debate in the medical community. Forgione et al. (2009) state that medical community questioning the effect of DRG system that uses payment control and health service quality control. In several previous researches, the researchers of DRG put more attention to the damage of the system on the organization. Even though the topic is interesting and important to be studied, yet it can be seen only from one perspective. Some researchers about DRG evoke the different response from the management of the hospital. One of the effects of the DRG system is the rationalization. The rationalization happens because the DRG system has the same standard, but it is adopted by the different hospital. The effect is the standardization of case mix for the different specialization medic. Even if this is hard to be done due to the probability of complex cases that are treated.

Havighurst (1984) states that DRG system is used as the effort in controlling doctors to rationalize the treatment. As stated by Goodman \& Musgrave (1992) the DRG system causes the rationalization of new medical technology, this happens if the claim from DRG is too low in service so the technology will not be provided to the patient in need. The use of rationalization in medical technology is closely related to the budget allocation. Thompson (1987) states that the rationalization of the budget is needed to provide services related to case mix. Since in the past, there has been no hospital that used the DRG system as the payment method, so the need for changing the operational pattern could not be realized. This happens due to the length of time for budget allocation so the advantages of change could not be delivered. That is why the process of budget allocation should be designed for this purpose.

The rational view in the change of organization is needed in improving substantive performance, such as efficiency and effectiveness. Meanwhile, based on the institutional theory, the organization change aims to get formal legitimacy. The organization changes based on the 
stakeholders' expectation. Based on Dimaggio \& Powell (1983), the organization tends to imitate the other organizations that are assumed to be the best. As a result, the organization in the same field tends to have the same theory and process called as institutional isomorphism. With the reference to the institutional theory, INA-CBG system has the important role in changing the hospital system. This system can be used as a ceremonial system to create and affirm the rule that exists. It also demonstrates the organizations are in accordance with the social norm and seem normal for the external party. In this case, the government and BPJS that are the payer of health services in JKN program have to improve the efficiency and make the autonomous decision that is called decoupling by Meyer \& Rowan (1997).

From several phenomena of the DRG implementation, the researcher interested to discuss the implementation of the INA - CBGs system in one of the regional public hospitals by using the institutional theory perspective. The implementation of the INS - CBGs system for the national health insurance in Indonesia is still new. The research on the implementation of the DRG in Indonesia's hospital has been conducted by Fahlevi (2014) that investigated on the accounting innovation after the implementation of DRG. The result of the research assessed that there were no significant changes in the accounting innovation in Indonesia's hospital since the implementation of DRG. The research about DRG used institutional theory has also been conducted by Covaleski et al (1993) showed that there were many elements in an organizational structure such as case-mix accounting needed more adaptation in the practice to be accepted by the society as a technique in developing a rationality. Casemix accounting plays the important role in building the legitimacy of social structure and considered as an interesting activity that potentially changes the operational process of internal finance in hospital. The research of Covaleski et al (1993) also broadens the institutional theory about the authority issues and decoupling where individual and organization as the subject of systematic examination in the certain context. This research has a different focus with the Covaleski et al. (1993) since the institutional pressure is the main analysis in the implementation of INA-CBGs system. The use of institutional pressure as the tool to analyze the system has also been conducted by Najeeb (2014) to analyze the practice of HRM in Maldewa Resort.

\section{LITERATURE REVIEW AND HYPOTHESES}

\section{Institutional Theory}


The research about institutional theory involves several fields such as economics, sociology, politic, and organizational theory. That is why there is a lot of people interested to conduct research which is related to institutional. Institutional theory has also become one of the choices in understanding the change process and sustainability of public sector organization in several researchers. Caemmerer \& Marck (2009) conducted an investigation on how the isomorphic pressure in institutional theory gave some effects on the orientation of public services. The institutional theory also based on the fact that the organizations are embedded in broader institutional contexts (Dimaggio \& Powell, 1991). This brings the consequences of an organization's practice of reflecting or responding to the rules and structures are built into the wider environment (Paauwe \& Boselie, 2003). Meyer \& Rowan (1977) further explain that the institutional environment is the source of a legitimacy, the emergence of rewards or incentives, and sanctions on organizational activity.

The relevance of institutional theory to the analysis of the implementation of DRG systems was originally undertaken by Covaleski et al. (1993). The use of institutional theory for organizational analysis is called by Greenwood et al. (2008) as an organizational institutionalism. Organizational institutionalism is closely related to how institutional perspective can be used to know about an organization's behavior. In this case, the institutional theory is an appropriate tool for analyzing organizational behavior from the empirical gap, namely the gap between the results of research with established theory.

\section{Institutional Pressure}

DiMaggio \& Powell (1983) explain that the organizational field is an organization that is aggregately recognized in its institutional as key suppliers, resources and product consumers, institutional rules, and other organizations that produce similar services or products. The existence of a common set of organizations in the organization field of institutional theory is called isomorphism. An isomorphism is a central value of institutional theory (Murphy \& Garavan, 2009). Isomorphism occurs within an organization because of a rational response to the same environmental conditions (Hannan \& Freeman, 1977). Dimaggio \& Powell (1983) call connectivity as the cause of isomorphism. The activity, system or structure that is considered as the best from the previous organization lead to new organizational pressures to follow the system (Dimaggio \& Powell, 1983). This pressure makes other organizations to increase their legitimacy 
over performance (Meyer \& Rowan, 1977). Dimaggio \& Powell (1983) identify three mechanisms of institutional isomorphism, namely coercive isomorphism, normative isomorphism, and mimetic isomorphism.

Coercive isomorphism is the adjustment due to the coercion of certain parties such as politics and stakeholders. Ashworth et al. (2009) say coercive pressure is caused by governments, regulations, or institutions that provide resources to adopt the structures or systems. This pressure may have resulted from contractual obligations with other parties. Generally, organizations accept this pressure as a force, or an invitation to join a coalition (Meyer \& Rowan, 1977). As a result of this pressure, the organization will align their behavior with the pressure to fulfill the role of constituents in society or gain legitimacy (Meyer \& Rowan, 1977). In relation to the implementation of the INA-CBGS system, coercive institutional forces include the influence of social partners (A House Association, Council), government policies, laws and regulations on health systems in Indonesia. This mechanism can be seen at various levels (international, national and industry level). International-level pressure includes international health conventions, while national level regulatory pressure includes national health insurance legislation $(\mathrm{JKN})$, and industry-level regulatory pressure includes interhospital agreements in Indonesia.

Normative isomorphism is an adjustment due to additional knowledge gained from formal education that has to be applied within an organization. Normative isomorphism according to Dimaggio \& Powell (1983) is associated with professionalization which is often defined as the collective struggle of members to determine the conditions and methods of their work to control producer production and to establish cognitive bases and legitimacy of their work autonomy. As professionalism increases within the organization, then there will be a normative belief in the organization. This adjustment can also be said as the application of norms and values of other organizations into an organization due to the existence of organizational isomorphism. Organizational isomorphism can also harm an organization because the norms and values, used as benchmarks, are no longer effective. In addition, it can also lead to the loss of creativity in the organization. The professionalism of employees influences policies and responses related to the implementation of INA-CBGS system.

Mimetic pressure is the pressure to copy or mimic the activity, system or other organizational structures (Ashworth et al., 2009). Meanwhile, according to Dimaggio \& Powell 
(1983), organizations imitate other organizations in the same field that are considered more successful when organizational technology is poorly understood, ambiguous goals or the environment creates symbolic uncertainty. This adjustment process is not only for efficiency purposes but also when an organization wants its products to be sold in the market. Organizations that make this type of adjustment are usually in a business environment that is rapidly changing and has high uncertainty. The research of Caves \& Christensen (1980) shows that larger organizations tend to be more stable and have high success in running their businesses. This happens because the organization has large resources so they are able to run the best strategy for its business. The public hospital is seen as a hospital which has huge resources, it should be able to become a model of the best hospital in the vicinity. There are three types of mimetic pressure, according to Haunschild \& Miner (1997), namely outcome-based imitation, frequency-based imitation, and trait-based imitation. Outcome-based imitation focuses on mimicking other organizational practices that have proven to be successful in the past. Frequency-based imitation focuses on mimicking the practices that have been adopted by most organizations. While trait-based imitation focuses on mimicking other organizational practices that resemble in some aspects.

\section{Organizational Strategic Response to Institutional Pressure}

The response of organizations to institutional pressure has become a concept as a strategic choice (Goodstein, 1994). In this case, the organizations have different strategic choices with other organizations. Oliver (1991) suggests that the differences in strategic responses to institutional pressure are adjusted to protect their interests. There are 5 strategic responses identified by Oliver (1991), They are approval, compromise, avoidance, disobedience, and manipulation. The choice of organizational response is influenced by various factors such as the nature of the institutional pressure and the type of resources that its constituents are supplied to the organization such as financial resources and the reputation of public opinion.

Oliver (1991) provides five strategic responses that may be chosen by the organization in response to institutional pressure. First, the organization will comply with institutional pressure. This organization has a high dependence on those who expect an adjustment to institutional demands. Scott (2008) explains that organizations tend to do the same imitation with mimetic tactics to adapt to the institutional environment. 
Second, organizations face multiple problems and conflict with the pressures of institutional environments or when organizations are in situations of inconsistencies between institutional demands and internal organizational goals. In these circumstances, the organizations tend to compromise to balance, soothe, or bargain with its institutional constituencies (Oliver, 1991). The organizations will adopt a balancing tactic in order to reach an agreement between various stakeholders and its internal interests (Oliver, 1991). Organizations will apply bargaining tactics that are a form of active compromise to deal with the mild degree of resistance to institutional pressure.

Third, organizations respond to institutional demands by evasion. Oliver (1991) declares avoidance is done by the organization to prevent the need for adjustments. Organizations perform avoidance tactics in three ways, namely: concealment, buffering and escaping. The concealment tactic is an organized effort to avoid incompatibility using convert way behind the approval (Oliver, 1991). While the buffering tactics is done by reducing the possibility of an external inspection, audit, and evaluation of the parties to institutional pressures (Scott, 1987). A more dramatic tactic, according to Oliver (1991) is escaping; the organization left the institutional environment under pressure. Organizations do this to avoid the need for adjustments that do not fit their goals and activities. Out of the three tactics, organizations are more likely to use concealment tactic when encountering with external regulatory demands (Scott, 2008). To avoid the inspection from external parties, organizations show that its works are accordance with the social norm while improving efficiency and make autonomous decisions that can be called by decoupling by Meyer and Rowan (1997). Brunsson (1989) often calls the term decoupling as an organized hypocrisy when the works are contrary to the report. Oliver (1991) declares a strategy of decoupling as a medium-term strategy, making some compromise and doing evasion.

Fourth, organizational disobedience refers to a strong resistance to the institutional pressure that may involve tactics such as dismissal, challenges, and attacks. This strategy is chosen by the organization when the organizational norms and interests differ substantially from the requirements imposed on the organization (Scott, 2008).

Fifth, the organization conducts a response by manipulating. Oliver (1991) refers to manipulation as a focused and opportunistic attempt to elect members on the approval of other members, influence, or control institutional pressure and evaluation. Organizations may cooperate with their constituents to be part of the play. While controlling tactics involve 
organizational efforts to build power and control over institutional constituencies that create pressure, organizations can also manipulate the form of collective responses (Scott, 2008), and choose more than one strategy in response the institutional pressure (Clemens \& Douglas, 2005).

\section{Design of DRG System Indonesia}

The INA-CBGs system is part of the health sector reform in Indonesia was first introduced in 2006. Indonesia implements a prospective payment system to control health costs and encourage quality health services. The purpose of using the INA - CBGs system in dealing with the increase in health expenditures is to achieve efficient cost. The efficiency of maintenance costs can be achieved by performance-based budgeting that oriented on people's need (Hasaart, 2011). Most of the Indonesian INA - CBGs systems resemble DRG systems. This INA-CBGs system classifies patients in the clinical group and at the same cost. This system allows condensing the activities of medical professionals in a range of products that can be measured by management systems and used to direct systems to have better performance (Abernethy \& Stoelwinder, 1995).

If we compare DRG systems in other countries, the INA - CBGs system has different characteristics. First, there are six clusters of hospitals, which have different rates. Secondly, regionalization rates are divided into 5 regions based on the Consumer Price Index (CPI). Third, the existence of additional payments (Top Up) for certain cases that include in special Casemix Main Group(CMG), including special procedures, special drugs, special investigation, special prosthesis, and special groups subacute and chronic. Fourth, there is no difference in the rates between public and special hospitals. Fifth, the rates cover all components of hospital resources used in medical or non-medical services.

\section{METHODS}

RSUD Dr. Saiful Anwar is located on J1. Attorney General Suprapto No. 2 Malang City East Java Province. The number of residents who become the coverage of RSUD Dr. Saiful Anwar Malang covers more than 10 million people, including Malang City, Malang Regency, Batu City, Pasuruan City and Regency, Probolinggo City and Regency, Lumajang Regency, Blitar City and Regency, Kediri Regency, and Jember Regency. RSUD Dr. Saiful Anwar Malang represents a public hospital that implemented the INA-CBGs system. In addition, Dr. Saiful 
Anwar Malang is A type hospital and is designated as one of the tertiary referral hospitals with BLUD status.

The informants in this research are 6 people consisting of the Head of Installation of IUD and Cooperation Unit (IKPK), Head of Medical Record Subsection, Coordinator of information system and financial data, Senior nurse, the INA-CBGs coding coordinator, medical records staffs, and coordinator software of INA-CBGs. The informants in this research are considered to understand INA-CBGs and their work is related to the INA-CBGs system in RSUD Dr. Saiful Anwar Malang.

This research uses a qualitative approach. Zalan \& Lewis (2004) explains that the choice of research methodology should be based on the objectives, nature of the problem, and the theory of the research. The author chose a qualitative method because it in accordance with the objectives and the research problem as well as to solve the complex social phenomena as described by Miles and Huberman (1994). Case studies are used as a strategy for this research to answer the problems that use "how" questions and require in-depth analysis (Yin, 2009). Sukoharsono (2006) explains case studies needed to explore something or some structure of the system or case in detail. Through case research, the researcher can confirm the theory with the results of research whether there is a match or there may be differences due to different research conditions. This research uses the interpretive paradigm. The interpretive paradigm emphasizes the meaning of each individual in shaping social reality. So that social reality can change depending on the meaning of the individual (Mulawarman, 2010). Through an interpretive paradigm, the researcher can draw an outline of different informant's meanings in generating a statement to answer the research problem.

The data analysis technique used in this research consists of three components, namely data reduction, data presentation, and a conclusion. Sukoharsono (2006) states data analysis is conducted by finding the order of data pattern. This finding is done to find something that will be displayed in the results of research because it is considered important. Data analysis is conducted by finding the order of data patterns in depth to be able to present the results of research in accordance with research purposes that can be text, tables, and drawings.

\section{RESULTS}

This section reviews the institutionalization process of the implementation of the INA - CBGs system within public hospitals to answer predetermined research questions. According to 
Dimaggio \& Powell (1983), organizations have the pressure to imitate other organizations that are considered the best. Consequently, organizations that are in the same field will tend to have the same form and process referred to institutional isomorphism. Pressure to institutional isomorphism described by Dimaggio \& Powell (1983) into three issues, they are 1) coercive isomorphism derived from political influence and legitimacy issues; 2) mimetic isomorphism derived from the standard response of uncertainty, and 3) normative isomorphism is associated with professionalism.

\section{Coercive Institutional Pressure and Organizationional Strategic Response}

The most common forms of coercive pressure are laws and regulations (Harcourt et al ., 2005). Presidential Regulation no. 12 The year 2013 on Health Insurance is one of the most common sources of coercive pressure related to the implementation of the INA-CBGs system in RSSA. As a public hospital, RSSA cannot avoid this rule and must implement it. The institutionalization process of INA-CBGs system by RSUD Dr. Saiful Anwar Malang was conducted by management in response to the laws and regulations. This response is manifested in the form of consent and compromise. Inevitably, RSSA must approve to run the program from the government as a form of legitimacy in the public perspective as the primary hospital of JKN. Approval by Oliver (1991) refers to conformity with institutional pressure. Interviews were conducted with respondents, it has been two years since the introduction of the INA-CBGs system as a claim payment system. Management of RSUD Dr. Saiful Anwar said they adopted various strategies such as capacity building of human resources to meet the requirements of legislation when the system was introduced. Hospital management used a proactive approach to align their policies and procedures with the rules in implementing INA - CBGs system. Management was familiar with the use of this system because previously they also applied the system in the Jamkesmas program although it was not exactly the same. This is in accordance with the following statement of respondents.

"The INA-CBGs was previously using the name of INA-DRG in Jamkesmas, then in 2014 INA-CBGs was implemented where SJSN law must be executed. The hospitals must have been prepared several ways, such as the improvement of hospital staffs in the implementation of INA-CBGs itself ". (Mr. Gik) 
"At the beginning of the implementation, there were so many obstacles, but we solve the problems well. The problem related to the software or from the side of other variables that support the implementation INA-CBGs itself ". (Mr. Gik)

The form of compromise made by management in response to the INA-CBGs system is a form of management's unpreparedness in setting the required service standards. The implementation of the INA-CBGs system requires public hospitals to improve their effectiveness and efficiency to reduce the loss. Some forms of compromise made by management, such as a compromise in the rules of writing diagnosis and improving strategies during the implementation.

The provision for the coding has been ruled under the National Healthcare Act. Based PMK No. 27 on the technical guidance of the INA-CBGs system, the duty, and responsibility of a coder is to codify the diagnosis and actions / procedures written by the doctor in accordance with ICD-10 for diagnosis and ICD-9-CM for actions / procedures. The reality in the field showed some managers at the SMF and inpatient Installation interpreted this provision in the different ways. There were still many diagnoses coding was not written by the doctor. Usually, the coding process is run by nurses who already have a review of diagnostic coding, this knowledge can be obtained through training or out of habit.

"Often found the doctor was busy and some high schooler, D3 and so forth, already have the coding in the room, for example, appendix policy number, wrote the diagnose. The doctor writes laparotomy numbers, but when it's done, they do not know it's wrong, we always recheck it again". (Mr. Nur)

"Whether the coding writes by nurses, doctor or anyone, when he comes here we will recheck it again, here I have to write a feedback every month. If it's wrong, we change it and report it, every month for every SMF that has been coded 100 , the true is 30 and wrong are 70 . When there is an increase of truth, we analyzed it". (Mr. Nur)

Management also used buffering tactic when there are rules that require the implementation of INA-CBGs. The buffering tactic involves ways to reduce the possibility of external examination through some techniques of decoupling activity from external contacts (Scott, 1987). The free service payment previously applied in RSSA requires further understanding and adaptation of the case-mix system. In addition, the absence of a legislative system that specifically regulates fraud for the INA-CBGs system made hospitals were likely to perform fraud either intentionally or unintentionally. Various forms of fraud that occurred were the decreasing standard of care, fragmentation of care, and unnecessary treatment. These frauds 
happened due to multiple INA-CBGs rates that had not been sufficient to provide services according to Evidence-Based Medicine. Dr. Saiful Anwar had previously been checked by external parties when implementing a case-mix system of Jamkesmas program. Since the potential for fraud was very large, then the management was trying to minimize the occurrence of fraud to mitigate the external examination. One strategy that was used was to form a separate installation for special financial matters and internal verifiers claims administration.

\section{Normative Pressure and Organizational Strategic Response}

Normative forces refer to the impact and influence of the professional standards to the practice of the organization (Asworth et al., 2009). Education and training system that are organized by the government and other educational institutions provide professional job qualifications (Maurice et al., 1986). So, the educational system and training institutions for medical recorders have an influence on the success of the INA - CBGs system. INA - CBGs system requires the hospitals to have qualified human resources especially for coding and medical records. But in reality, high-quality educations in medical records departments were very limited. This is in accordance with the following respondent's statement.

"S1 medical records with associate colleges (APIRMIX) has not existed until now because it is new research programs than others. We make the association college medical records throughout Indonesia to equalize the curriculum, so the curriculum in UGM will be the same in Malang. The curriculum has already finished. If S2 was joined as public health. The special SKM of S2 should be special ". (Mother Nung)

The source of normative pressures in the implementation INA - CBGs comes from needs of the professional medical recorder and the demand for certification for medical records. The regulation of Health Ministry No. 55 of 2013 regulates the job of medical recorders in the hospital. This regulation requires medical records to have a Certificate of medical records (STR) and Work Permit of medical records (SIK). To be able to have SIK, medical records must have STR. STR is released by the Assembly of Health Personnel Indonesia (MTKI) with a validity period of 5 years. MTKI serves to guarantee the quality of medical professionals who provide health services. Medical record staffs are also required to have a health information system that can be submitted to the department of health in the county. In addition, this certification is intended to improve the competence and quality of medical records. It is also in accordance with the following respondent's statement. 
"Must have because what they are professional. If it is a profession should have STR, SIK is work permit. STR is usually given to the college or department, which releases in the provincial health bureau. The validity for the medical record was 5 years but the validity of nurses and other is 2 years". (Mr. Nur)

"Yes, there are two P2T even at the ICM center, the honoree must have, they should have a right to accreditation yesterday we had a credential team such as nurses and doctors. Actually, from the ministry if it is not one a test, it will be packed in the form of training, so the government invited all coding hospitals throughout Indonesia to Jakarta approximately 1 week. Constantly, the tests on codification is to know their level of knowledge, after that there are training and test again to increase the level". (Mother Nung)

The implementation of the INA - CBGs system carries changes in the needs of professionals human resources in the field of medical records. Medical records are an important factor in supporting the success of INA - CBGs system. An increasing number of JKN patients make the hospital to keep the pace with the increasing number of medical recorders to accelerate the administration process.

The education of medical records in Indonesia is still not effective and there is a lack of training from the government. One of the strategies is conducting strict selection in hiringa medical records. There are several stages of tests that must be passed by the prospective medical records before it is set to be a hospital employee. One of the tests that are required to be followed is the skill test. These tests look at the actual capabilities of the prospective medical recorder with materials such as coding analysis, planning how to fill the correct coding and so on. The medical recorders have to conduct not only written test and compulsory basic capabilities but also other abilities. The following statement of the respondent on this point.

"They come first, they must pass a test, after passing the test he must pass through the skill test, the material is related to the analysis, coding, how charging, then writing reports. The material is Miscellaneous No 10, and it took 2 days. Not only that, anyone who wants to enter here, for example as a D3 medical record should do the skill test, so that we know the ability, if you have a basic, you will be allowed in here ". (Mr. Nur)

Besides imposing a strict selection with a variety of tests, the hospital Management also conducted early regeneration. The regeneration of medical records for the purposes of INA CBGs coding is very urgent since most employees have already entered the full-time duties. Regeneration of medical records for INA-CBGs coding is done to provide more knowledge and competence for the new medical records. Knowledge of INA - CBGs coding is 
essential to increase the number of revenue claims accepted by the hospital. Total revenue claim accepted by the hospital is very dependent on the completion status of the diagnosis of patients.

\section{Mimetic Pressure and Organizational Strategic Response}

Mimetic forces are the pressure to copy or mimic the activity, system or other organizational structures (Ashworth et al ., 2009). The mimetic pressure on the implementation of the INA - CBGs system was a tight competition with other hospitals and healthcare industry that is full of uncertainties. The environmental health industry is currently very competitive, it can be seen from the number of hospitals in the region that provide services equally. Hospital of Dr. Saiful Anwar typically competed with other public hospitals and private hospitals in East Java. Furthermore, if the hospital fulfills its vision as an international hospital, it also will compete with hospitals in Malaysia and Singapore. Some of these competitors may have greater financial resources, human resources, and other resources.

Dr. Saiful Anwar hospital as the Public Service Board (BLUD) is required to provide services to the community and developing its business units. In developing its business unit, it would not be separated from a variety of business risks. The business risks can affect the continuity of the hospital business. Risks related to the business activities of the hospital as BLUDs are when the organization continues to achieve opportunities for growth. Risks that would be faced with such a situation, for example, difficulty in recruiting, training and retaining qualified medical personnel. Recruitment of medical personnel who have civil servant status would have to be approved by the central government. This can be seen from the lack of professional medical personnel such as medical records, nurses, midwives, and doctors who have the status of civil servants (PNS).

Another risk is the difficulty in integrating information systems and technologies that must be the main strategy for implementing the INA-CBGs system. Systems and information technology is very important for a number of areas of hospital operations include accounting and financial reporting, diagnose a medical, patient care, medical records and document storage, and management of drug supplies. Moreover, the risk of funding can be a very serious concern when the majority of hospital revenue is coming from BPJS patients that require the implementation of the INA - CBGs system to maintain hospital operations.

\section{Picture 1}




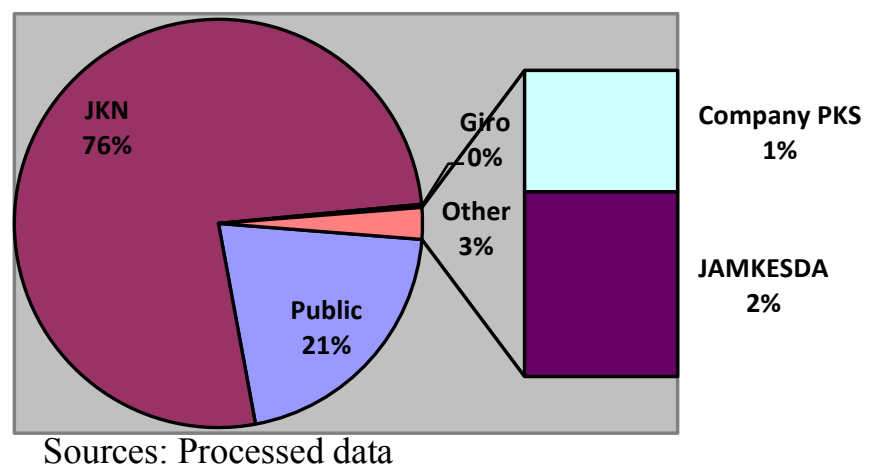

Figure 1. Realization of Operational Revenue of RSUD Dr. Saiful Anwar year 2016

There are a variety of organizational responses to mimetic pressure, but the most common responses as revealed by Dimaggio and Powell (1983) is imitation. Imitation is often carried out by an organization in an uncertain environment. One form of imitation which is done by RSA is benchmarking strategy. The strategy of benchmarking conducted by the hospital cannot be separated from the INA - CBGs system. Implementation of INA-CBGs system makes the hospital should be able to control their costs while maintaining service quality. Management considers other hospitals that have been able to do this by establishing an internal control team. It is expected that the doctor's diagnosis is effective and in accordance with INA - CBGs package rates. In addition, management also performs an impersonation of another hospital that has the same market share, namely the hospital of Dr. Soetomo Surabaya. One form of impersonation performed by Dr. Saiful Anwar hospital against Soetomo is forming a special installation in charge of financing BPJS by name IKPK (Installation of Health Financing Agreement). Some hospitals may have a name that is different, but the essence is the same. This installation is formed to increase the speed of the hospital administration to BPJS. This is in accordance with the following respondent's statement.

"Yes, this is probably a lot to do with the management policy, but I think it is also important because with the installation of this right can automatically improve the performance of a health care cooperative installation means that later it will improve the claim pace. Even Soetomo hospitals own IKPK in advance, but I do not know more details, perhaps management could explain but technically as it is ". (Mr. Gik) 


\section{CONCLUSION}

The main objective of this research is to understand the implementation of the INA - CBGs system through the perspectives of institutional pressure and organizational strategic response in Dr. Saiful Anwar (RSSA) hospital. Dimaggio and Powell (1983), and Scott (1995) has explained about the three forms of institutional isomorphic forces that may be experienced by the organization. In this research, there are three sources and mechanisms of institutional pressures experienced by the Dr. Saiful Anwar hospital in the implementations INA-CBGs system namely coercive pressure, normative pressure, and mimetic pressure.

Coercive pressure is caused by government regulations that require public hospitals to apply the INA-CBGs system as a method of claim payment. The RSSA management responded to the coercive pressure with passive approval. Management often meets the requirements of the JKN law that is in line with the needs of the hospital business which is called as a compromise by Oliver (1991). The RSSA management also undertakes an innovation strategy to meet institutional requirements when the regulations of the INA-CBGs system opposed the internal objectives of the organization. The finding of this research is in accordance with Boon et al (2009) which state that the organization can opt for innovative development to balance the competitive institutional pressure in achieving efficiency and sustainability.

Normative pressure derived from the standard of education and professionalism of the medical record staffs. The profession of medical record has an important role in determining the number of claims received by the hospital. The strategic of government for medical recorders is through the regulation of expertise certification. This regulation is responded by hospital management by holding the recruitment of staffs more selectively according to their level of education and experience.

Mimetic Pressure in the implementation of INA-CBGs comes from the competition and the uncertainty of the health industry environment. The competition with other hospitals that have the same type of providing services can be one of the reasons for RSSA to implement a better payment system. Environmental uncertainties of funding sources, which most of its revenue came from BPJS, required the use of INA-CBGs system. Strategic response of RSSA management to face the mimetic pressure is by imitating practices from other hospitals as expressed by ( Dimag gio \& Powell, 1983). The management established an IKPK installation that specifically tackles financing co-operation to accelerate the claims administration 
process. This research uses institutional theory only in the aspect of institutional pressure. The use of institutional theory from other aspects can also be used for further research, such as the process of institutionalizing INA-CBGs system

\section{REFERENCES}

Abernethy, M., \& Stoelwinder, J. (1995). The role of professional control in the management of complex organizations. Accounting, Organizations and Society, Vol. 20(1), pp. 1-17.

Ashworth, R., Boyne, G., \& Delbridge, R. (2009). Escape from the Iron Cage? Organizational change and Isomorphic Pressures in the Public Sector. Journal of Public Administration Research and Theory, Vol. 19(1), pp. 165-187.

Boon, C., Paauwe, J., Boselie, P., \& Hartog, D. (2009). Institutional pressures and HRM:developing institutional fit. Personnel Review, Vol. 38 Iss 5 pp. 492 - 508.

Brunsson, N. (1989). The organization of Hypocrisy: Talk, Decisions, and Actions in Organizations. New York, Wiley.

Caemmerer, B., \& Marck, M. (2009). The impact of isomorphic pressures on the development of organisational service orientation in public services. In: Australian and New Zealand Marketing Academy.

Caves, D. W., \& Christensen, L. R. (1980). The relative efficiency of public and private firms in a competitive environment: the case of Canadian railroads. Journal of Political Economy, Vol. 88, pp. 958-976.

Clemens, B. W., \& Douglas, T. J. (2005). Understanding strategic responses to institutional pressures. Journal of Business Research, Vol. 58(9), pp. 1205-1213.

Covaleski, M. A., Dirsmith, M. W., \& Michelman, J. E. (1993). An Institutional Theory Perspective on the DRG Framework, Case-mix Accounting Systems and Health-care Organizations. Accounting. Organizations and Society, Vol. 18, issue 1, pp. 65-80.

DiMaggio, P., \& Powell, W. (1983). 'The Iron Cage Revisited: Institutional Isomorphism and Collective Rationality in Organizational Fields'. American Sociological Review, Vol. 48, pp. 147-160.

DiMaggio, P., \& Powell, W. (1991). Introduction. The New Institutionalism in Organizational Analysis. University of Chicago Press.

Fahlevi, H. (2014). Accounting Innovations After the Adoption of Diagnostic Related Groups (DRGs) Provider Payment System. International Accounting Conference and 2nd Accounting Students Research Forum, Universitas Indonesia Depok, 24-25 November 2014.

Forgione, D. A., Vermeer, T. E., Surysekar, K., Wrieden, J. A., \& Plante, C. A. (2009). The Impact of DRG-Based Payment Systems on Quality of Health Care in OECD Countries. Journal of Health Care Finance.

Goodman, J. C., \& Musgrave, G. L. (1992). Patient Power: Solving America's Health Care Crisis. Washington: Cato Institute. 
Goodstein, J. (1994). Institutional pressures and strategic responsiveness: Employer involvement in work-family issues. Academy of Management Journal, Vol. 37(2), pp. 350-382.

Greenwood, R., Oliver, C., Sahlin, K., \& Suddaby, R. (2008). Introduction. The Sage Handbook of Organizational Institutionalism. London, SAGE Publications: 1-46.

Hannan, M. T., \& Freeman, J. (1977). The population ecology of organisations. American Journal of Sociology, Vol. 82(5), pp. 929-964.

Harcourt, M., Lam, H., \& Harcourt, S. (2005). Discriminatory Practices in Hiring: Institutional and Rational Economic Perspectives. The International Journal of Human ResourceManagement, Vol. 16(11), pp. 2113-2132.

Hasaart, F. (2011). Incentives in the Diagnosis Treatment Combination payment system for specialist medical care. A research about behavioral responses of medical specialists and hospitals in the Netherlands. (Doctoral thesis), Maastricht: Universitaire Pers Maastricht.

Haunschild, P. R., \& Miner, A. S. (1997). Modes of interorganizational imitation: The effects of salience and uncertainty. Administrative Science Quarterly, Vol. 42(3), pp. 472-500.

Havighurst, C. C. (1984). Doctors and Hospitals: An Antitrust Perspective on Traditional Relationships. Duke Law Journal, Vol. 6, pp. 1071-1162.

Hopwood, A. G. (1992). 'Accounting Calculation and the Shifting Sphere of the Economic'. European Accounting Review, Vol 1, no.1, pp. 125-143.

Maurice, M., Sellier, F., \& Silvestre, J. (1986). The Social Bases of Industrial Power.Cambridge, MA, MIT Press.

Meyer, J., \& Rowan, B. (1977). 'Institutional Organizations: Formal Structure as Myth and Ceremony’. American Journal of Sociology, Vol. 83, pp. 340-363.

Miles, M., \& Huberman, B. (1994). Qualitative Data Analysis. London, Sage.

Mulawarman, A. D. (2010). Integrasi Paradigma Akuntansi: Refleksi Atas Pendekatan Sosiologi Dalam Ilmu Akuntansi. Jurnal Akuntansi Multiparadigma, Vol.1 No.1 April 2010.

Murphy, A., \& Garavan, T. N. (2009). The adoption and diffusion of an NHRD standard: A conceptual framework. Human Resource Development Review, Vol. 8(1), pp. 3-21.

Najeeb, A. (2014). How do Institutional Forces Shape HRM Practices? A Research of Tourist Resorts in the Maldives. Doctor of Philosophy thesis,School of Management, Operations and Marketing, University of Wollongong.

Oliver, C. (1991). "Sustainable competitive advantage: combining institutional and resourcebased views". Strategic Management Journal, Vol. 18, No. 9, pp. 697-713.

Paauwe, J., \& Boselie, P. (2003). Challenging 'strategic HRM' and the relevance of the institutional setting. Human Resource Management Journal, Vol. 13(3), pp. 56-70.

Peraturan Menteri Kesehatan Nomor 55 Tahun 2013 Tentang Penyelenggaraan Rekam Medis.

Scott, W. R. (1995). Institutions and Organizations. Thousand Oaks, CA, Sage.

Scott, W. R. (1987). The adolescence of institutional theory. Administrative Science Quarterly, Vol. 32(4), pp. 493-511. 
Scott, W. R. (2008). Institutions and Organisations: Ideas and Interests. Thousand Oaks, CA, Sage.

Sukoharsono, E. G. (2006). Alternatif Riset Kualitatif Sains Akuntansi: Biografi, Phenomenologi, Grounded Theory, Critical Ethnografi dan Case Research. Dipublikasikan di Analisa Makro dan Mikro: Jembatan Kebijakan Ekonomi Indonesia hal. 230-245. BPFE Universitas Brawijaya.

Thompson, J. D. (1987). "With Cat-Like Tread, the DRGs are Coming". Journal of Management in Medicine, Vol. 2, Iss 3, pp. 193-207.

Yin, R. K. (2009). Case Research: Design and Methods ( $4^{\text {th }}$ Ed.). Thousand Oaks, CA:Sage.

Zalan, T., \& Lewis, G. (2004). Writing about methods in qualitative research: Towards a moore transparent approach. Handbook of Qualitative Research Methods for International Business. R. Marschan-Piekkari and C. Welch. UK, Edward Elgar Publishing Limited. 507-528. 